\title{
İngilizce Öğretmenliği Programındaki Öğrencilerin Çeviri ve Okuma Becerileri Arasındaki İlişsi Üzerine Bir Çalışma
}

\begin{abstract}
Serhan KÖSE*
ÖZ. Bu çalışmada çeviri becerisi ile okuma becerisi arasındaki ilişkiyi incelemek amacıyla deneysel bir araştırma yapılmıştır. Yapı ve anlam odaklı çeviri öğretimin yapıldığı çeviri dersinde öğrencilerin okuma becerileri ve çeviri becerileri karşılaştırılmıştır. Bu iki beceri arasında bir ilişki olup olmadığı araştırılmıştır. Ölçme araçları olarak İngiliz Dili Eğitimi alanında uzman üç eğitimci tarafından hazırlanan çeviri testi ve ÖSYM (Öğrenci Seçme ve Yerleştirme Merkezi) tarafindan düzenlenen KPDS (Kamu Personeli Yabancı Dil Bilgisi Seviye Tespit Sınavı) sınavından okuma parçaları seçilmiş̧ir. Çalışma Gazi Ünivesitesi, Gazi Eğitim Fakültesi, İngiliz Dili Eğitimi Anabilim Dalı ikinci sınıf öğrencileriyle gerçekleştirilmiştir. 2009-2010 güz döneminde uygulama yapılarak deney öncesi ve sonrası öğrencilerin okuma ve çeviri becerileri ölçülmüştür. Ayrıca öğrencilerin okuma becerileri iyi, orta ve kötü olarak seviyelendirilmiş ve seviyelerine göre çeviri becerileri ölçülmüştür. Çalışma sonucunda anlam odaklı çeviri öğretiminin yap1 odaklı çeviri öğretimine göre öğrencilerin okuma becerilerinin daha fazla yükselttiği ve ayrıca okuma düzeyi iyi ve orta olan öğrencilerin daha iyi çeviri yaptıkları saptanmıştır.
\end{abstract}

Anahtar Sözcükler: Çeviri, okuma becerisi, ilişki, yabancı dil öğretimi

\footnotetext{
* Öğretim Görevlisi. Kastamonu Üniversitesi, Eğitim Fakültesi, İlköğretim Bölümü.

Tel. +90 (366) 2142312 /133 E-posta: skose@kastamonu.edu.tr, serhankose@gmail.com
} 


\section{ÖZET}

Kapsam ve Önemi: Uzun yıllardır yabanc1 dil öğretiminde yap1 ve anlam odaklı öğretimin karşılaştırılması yapılmış ve halen hangi öğretimin daha etkin olduğu konusunda fikir birliğine varılamamıştır. Çeviri dersinde her iki öğretim kolaylıkla uygulanabilmektedir. Çevirinin sadece kelime ya da cümle düzeyinde olmadığı metnin anlam bütünlüğünün de önemli olduğu otoriteler tarafından kabul edilmiştir. Çevirinin ayrıca kültürel boyutu da bulunduğundan çeviri yapanların dil becerilerinin, kültürlerarası bilgi ve becerilerinin gelişmiş olması gerekmektedir. Çeviride, yabancı dil öğretiminin yapıldığı sınıflardaki uygulamalarda dil becerileri içerisinde okuma becerisi en önemlisi sayılmaktadır. Okuma ve çeviri becerileri benzer bilişsel özellikleri içermektedir. Bu araştırmada okuma becerisinin çeviri becerisine etkisi olup olmadığ 1 ve okuma düzeylerinin çeviri becerilerini şekillendirip şekillendirmediği araştırılmıştır.

Yöntem: $\mathrm{Bu}$ araştırmada İngiliz Dili Eğitimi Bilim dalındaki öğrencilerden seçkisiz oluşturulan deney ve kontrol gruplu desen kullanılmıştır. Deney grubu 40, kontrol grubu 35 öğrenciden oluşmaktadır. Araştırma 2009-2010 güz döneminde on hafta boyunca uygulanmıştır. Ölçme aracı olarak İngiliz dili eğitimi alanında uzman olan üç kişi tarafından belirlenen ve hazırlanan çeviri ve okuma ölçekleri kullanılmıştır. Kontrol grubunda her metnin incelenmesi esnasında metnin içeriği ile ilgili dilbilgisi verilmiş, denek grubunda ise dilbilgisi işlenmemiş metnin anlamı vurgulanmıştır. Deney öncesinde ve sonrasında bu ölçekler öğrencilerin seviyelerini belirlemek amaciyla öğrencilere verilmiş ve sonuçlar üç uzmanın değerlendirmesinin ortalaması alınarak ölçeklendirilmiştir. Sonuçlar SPSS 15.0 programı ile istatistik olarak değerlendirilmiştir.

Bulgular: Okuma ve çeviri testlerinde deney grubunun $(\mathrm{r}=0.033$, $\mathrm{p}>.05)$ ve kontrol grubunun $(\mathrm{r}=0.217, \mathrm{p}>.05)$ ön test sonuçları düşük seviyede pozitif bir ilişki olduğunu ortaya çıkarmıştır. Son testlerde ise deney grubunda orta düzeyde $(\mathrm{r}=.342, \mathrm{p}<.05)$ bir ilişki bulunurken kontrol grubunda ise düşük seviyede negatif bir ilişki bulunmuştur $(r=-0.012$, $\mathrm{p}>$.05). Okuma düzeyi düşük olan öğrencilerin okuma ve çeviri testlerinde anlamlı bir fark bulunmamıştır $\left[\mathrm{x}^{2}(3)=2.600, \mathrm{p}>.05\right]$. Orta $\left(\mathrm{F}_{(3-100)}=5,671\right.$; $\mathrm{p}<, 05)$ ve iyi düzeyde $\left(\mathrm{F}_{(3-29)}=5,556 ; \mathrm{p}<, 05\right)$ okuma becerisine sahip öğrencilerin test sonuçlarında anlamlı bir fark bulunmuştur. Anlamlı ilişki deney grubu ön ve son testleri ile deney grubu son testi ile kontrol grubu ön testi arasında bulunmuştur. 
Tartışma ve Sonuç: Deney sonunda ortaya çıkan sonuçlara göre okuma becerisi ile çeviri becerisi ön test sonuçları arasında düşük düzeyde ilişki olduğu ve uygulama sonunda deney grubunda bu ilişki yükselirken kontrol grubunda düşüş göstermiştir. Okuma düzeylerine göre yapılan değerlendirmede ise okuma becerisi kötü olan öğrencilerin çeviri becerilerinde gelişme göstermedikleri fakat okuma becerisi orta ve iyi düzeyde olan öğrencilerin çeviri becerilerinde gelişme olduğu kaydedilmiştir. Bu sonuçlar ışığında denebilir ki çeviri dersinde uygulanan öğretim yönteminin öğrencilerin okuma becerilerine etki ettiği ve anlam odaklı öğretimin yapı odaklı öğretime göre daha etkili olduğunu söylenebilir. Ayrıca okuma düzeyleri kötü olan öğrencilerin çeviri becerilerinde gelişme kaydedilmezken orta ve iyi düzeyde olan öğrencilerin çeviri becerilerinin gelişme gösterdiği saptanmıştır. Her iki öğretim yönteminin karşılaştırılmasında ise anlam odaklı öğretimin yapı odaklı öğretime göre daha yararlı olduğunu belirtilebilir. 


\title{
A Study on the Correlation between Reading Comprehension and Translation Skills of ELT Students
}

\author{
Serhan KÖSE*
}

\begin{abstract}
In this study, an experimental research was conducted to find out the correlation between the learners' translation skills and reading comprehension. The reading skills and translation skills were compared in the translation course in which form and meaning focused translation instruction treatment was given. The correlations between these two skills were investigated. The translation test was prepared by three experts in the field of English Language Teaching in evaluating the students' translation levels. The Reading Test was taken from the KPDS (State Staff Foreign Language Proficiency Exam) is a language examination administered in Turkey in order to evaluate the foreign-language skills, especially of governmental officials) which was prepared by the ÖSYM (Öğrenci Seçme ve Yerleştirme merkezi - Student Selection and Placement Centre). The treatment was done in the 2009-2010 fall semester and the reading and translation levels were scored before and after the treatment. Also, the translation skills were measured according to their reading levels which were graded as good, average and poor. The meaning focused translation instruction showed that it had improved the reading and the translation scores of the students better than form focused translation instruction.
\end{abstract}

Key Words: Translation, reading skill, correlation, foreign language teaching

\footnotetext{
* Instructer. Kastamonu University, Faculty of Education, Department of Elementary Education.

Tel. +90 (366) 2142312 /133 E-mail: skose@kastamonu.edu.tr, serhankose@gmail.com
} 


\section{INTRODUCTION}

Translation plays an important role in providing the necessary communication between people, societies and governments. For this reason, translation plays an important role in transmitting culture and the truth as accurate as possible. Wrong translation can be catastrophic and the mistake irreparable. Students should be aware of the fact that meaning is not only conveyed by the structure and words. Students must learn how translation is done and how it must be taught.

Duff (1994) states that "as a language learning activity, translation has a lot of merits:

- It invites speculation and discussion. In translation there is hardly any 'right' answer, but there are a lot of wrong ones. Doing all the work individually and in writing is not necessary. Students can work in pairs or groups for oral discussion. You may choose short texts for reading and discussion to save the time.

- Translation develops three essential qualities to all language learning: accuracy, clarity and flexibility. "It trains the reader to search (flexibility) for the most appropriate words (accuracy) to convey what is meant (clarity)" (p.48).

- 'Depending on the students' needs, and on the syllabus, the teacher can select material to illustrate particular aspects of language and structures the students have difficulty with. By working through these difficulties in the mother tongue, the students can see the link between the language (grammar) and usage" (p. 48).

Translation has an impact on improving language learning and is necessary for language learners. It will contribute to their language skills as well, because translation needs competency in not only the basic skills but also grammar, idioms and expressions. One of the important skill that needs to be competent in translation is reading.

People choose to read for different purposes. For example; they read for day to day survival, for general interest, for personal interest, for social purposes, for pleasure and aesthetic appreciation and for academic purposes. In line with this, the range of different texts to which readers are exposed in real life is extensive. For language learning reading is used: - to 'translate' the text, literally or metaphorically, - to learn new vocabulary, - to identify 'useful' structures or collocations, - to use the text as a model for writing and - to practice pronunciation (Davies, 1995, p. 2). 
Reading is a complex information processing skill in which the reader interacts with text in order to (re)create meaningful discourse. From this perspective, reading is understood to be a complex cognitive process in which reader and text interact to (re)create meaningful discourse. Contemporary reading theory puts text and the reader at its centre (Klein, 1988, p. 12).

The significance of the study is twofold; theoretical and pedagogical. On the theoretical level, the research is designed to examine how form and meaning focused translation treatment can be best conducted and which type of instruction has the greatest effects on the translating skills. On the pedagogical level, the existing Translation courses are designed to improve the students' academic translating skills and the course content differs according to the lecturer. Consequently, the study specifically aims to explore and offer ways of incorporating focus on form and focus on meaning treatment into Translation classes in order to eliminate the students' inaccuracies in their products. Also, this research is designed to find out if the level of reading comprehension has a positive effect on translation skills. It is to find out if the higher the reading comprehension level is the better translation will be.

\section{Literature Review}

\section{Definitions of Translation}

Shiyab and Abdullateef (2001) defines translation as “... transferring the meaning of a text from one language to another, and such transference has to account for the textual, grammatical and pragmatic meanings of the text to be translated, taking into account that meaning necessitates reference to linguistic and non-linguistic factors embedded within the text" (pp. 1-5). They also state that although the word-for-word translation and the grammar-translation methods are the earliest type of translation, one should note that interlinear translation is used in the grammar-translation method, whereas word for word and literal translation are used in contrastive analysis.

The term 'translation' can be used in different ways in various contexts. In a rather broad sense, Jakobson (1959) defined three types of translation: (1) intralingual translation, or rewording, refers to an interpretation of verbal signs by means of other signs in the same language; (2) interlingual translation, or translation proper, is an interpretation of verbal signs by means of some other language; and (3) intersemiotic translation, or transmutation, involves an interpretation by means of a nonverbal sign system. Among the three types of translation, interlingual translation can be 
considered a use of one's first language to understand and interpret another language, and is often used in the field of foreign language teaching and learning.

\section{The Place of Translation in Foreign Language Teaching}

From 1960s onwards, researchers have realized that translation activities have indeed merits which would contribute to language teaching. However, as Newmark (cited in Erer, 2006, p. 12) points out, the literature on teaching translation is rather scarce, although translation has been in the heart of language teaching for centuries. He also mentions that its place in language teaching is closely linked with how the use of students' native language is viewed in the language classroom.

However, according to recent studies carried out on the use of translation as a means for teaching and learning foreign languages, it is shown that translation can be a valuable tool if used appropriately (Erer, 2006, p. 12).

Newmark (1988) also states that "translation is a means of transmitting culture and the truth. It is a technique in learning language. Learners become aware of their knowledge of foreign language because of which they become more competent. Translation gives learners the pleasure of searching for the right word and the semantic gap between two languages. The relief of finding the right word is a reward for the learners" (p. 8).

"Translation requires a disciplined study, research on literature and culture, comprehending the theme and style of the text to be translated, getting to know the author, and defining the scope of the translation. Besides, students should have to define the similarities and differences between the languages and cultures. They should have to comprehend what they read, pay attention to the style and essence of the text being as faithful as possible to the text but making it comprehensible. They should first make a comparison of their translations and then read them a few times. Every sentence, paragraph, and section of the text being translated should have to be checked with utmost care" (Bozkurt et al, 1982, p. 19).

A significant test of many linguistic and even non-linguistic skills, translation provides students with a linguistically demanding, mind stretching, and creative exercise although this fact seems to have been ignored. In translation courses, students have to learn to make choices, analyse, criticise, and formulate (Webb, 1994, p. 10).

Translation requires the knowledge of two languages-native to second/foreign, foreign to native, for bilinguals two native languages. This 
may cause problems in translation. According to Nida (1975b) "the 'perfect translation' simply does not exist. All translation involves 1) loss of information, 2) addition of information, and/or 3) skewing of information" (p. 27).

Also Nida (1975a) has observed the following as important aspects in any semantic componential analysis of the translation procedure which can cause problems in translation:

(1) Features of single lexical units overlap (common or shared components) Love Like.

(2) Componential features distinguish the meaning of individual lexical units or lexical units with more than one meaning (diagnostic/contrastive).

(3) There are semantically optional features that often have a connotative character and can cause some metaphorical extensions (p. 73).

\section{Reading Comprehension}

In the past, reading was assumed to be passive, happening largely as a result of decoding and learning the meaning of individual words. According to Pearson (cited in Jones, Palincsar, Ogle \& Carr, 1987, p. 5) the goal of reading therefore was to 'approximate' the text.

Riley (1977) states that reading is a receptive skill. "The reader is expected to decode the visual form of the text into comprehension messages in the brain. The reader, then, has to integrate his reading abilities in order to decode the message correctly. So good readers read, ask themselves questions and make predictions about what will happen next" (pp. 1-6). He also points out that selecting main idea from the passage, selecting relevant details to support the main idea, recognizing irrelevancies, contradictions, using logical connections and sequence signals, drawing conclusions, making generalizations and applying principles to other instances are some of the skills that an intelligent reader has to be able to use for comprehension.

Now, it is accepted as private and active skill. Davies (1995) states that "it is a mental or cognitive process which involves a reader in trying to follow and respond to a message from a writer who is distant in space and time. Because of this privacy, the process of reading and responding to a writer is not directly observable" (p. 1). 
Reading comprehension is viewed as the process of using the cues provided by the author and one's prior knowledge to infer the author's intended meaning. This involves a considerable amount of inferencing at all levels as one builds a model of the meaning of the text. If prior knowledge is strong, then a detailed model may be rapidly constructed which reduces the reading to slot-filling and verifying, and inferences to mere default values in the model (Johnston, 1983, p. 9).

Goodman includes that (cited in Retorta, 2006): a reader, who was seen as an active agent in the reading process, would make predictions, create hypothesis or expectations about the text based on prior knowledge and check the text for confirmation or refutation of these expectations. Language knowledge was of secondary importance.

As it is stated the importance of reading in language classrooms is necessary. In learning a foreign language reading as a receptive skill is improved primarily in accordance with the productive skills.

\section{Good Readers and Poor Readers}

Fluent readers "read rapidly, recognize words rapidly and automatically, draw on a very large vocabulary store, integrate text information with their own knowledge, recognize the purpose(s) for reading, comprehend the text as necessary, shift purpose to read strategically, use strategies to monitor comprehension, recognize and repair miscomprehension, and read critically and evaluate information" (Grabe \& Stoller, 2001, p. 188). Thus, the processes involved in fluent reading are "rapid, efficient, interactive, strategic, flexible, evaluating, purposeful, comprehending, learning, and linguistic" (Grabe \& Stoller, 2002, p. 17).

According to Singer (1994), experienced readers differ remarkably from inexperienced readers in that they have attained automaticity in word recognition and usually focus their attention on higher-level processing, while inexperienced readers usually have to embark on an upsetting decoding phase, focusing their attention on the lower-level processing, i.e. on the constituents of discrete words. In the same vein, Grellet (1981) states that "proficient readers do not concentrate on sentences and words. Instead, they start with global understanding and then work toward comprehension of detailed aspects of the reading" (p.8).

Academic reading is a very deliberate, demanding and complex process. Lin (2002) lists the technical steps leading to L2 reading comprehension, briefly, as follows:

1) knowledge of form; 
a-word recognition: being able to recognize $\mathrm{L} 2$ words,

b-interpretation of words' meanings: automate the link between word recognition and word meaning,

c-syntactic knowledge: combination of words into larger units, and,

d-textual structure: organization of the text

2) knowledge of content

As stated above when reading, the learner has to have the knowledge of grammar, expressions, word meanings, textual and contextual knowledge.

As a result, briefly we can say that good readers: reread the text selectively, attempt to recite the text, constructing a summary of it, reflect on what they have just read, evaluating the credibility of the material, think about how they are going to use the information in the text, and evaluate their comprehension.

\section{The Importance of Reading in Translation}

Chastain (1988) also states that "Reading is also the skill which the students will have the greatest ability at the end of a course stressing the four language skills. They will also retain it longer than other skills. They will not be able to comprehend as much of what they hear due to the higher speed at which they are forced to process the message, and they will not be able to produce a message at the same linguistic level as the one at which they read" (p. 219). Also, Basnett (1998) points out that "translation offers a crucial lesson in how to read since it is a critical way into the text" (p. 111).

Macizo and Bajo (2004), done two experiments in their study, they examined reading comprehension processes when professional translators were instructed to read for understanding or to read for translation. Their findings have put forth interesting results. In their research Macizo and Bajo (2004) have come to a result that reading and translation has the same comprehension process and have concluded that "Language comprehension includes a set of processes going from speech processing (segmentation and classification of the incoming input), lexical access (recognition of isolated words and access to information associated with them), and sentential processing (extraction and combination of syntactic information to obtain a sentence interpretation), to discourse processing (integration and interpretation of successive sentences to arrive at a global mental representation). All of these comprehension processes are involved during both normal reading and translation" (Macizo \& Bajo, 2004, p. 181). Macizo 
and Bajo (2004) also put forth that "Hence, according to the horizontal view of translation, although normal reading and reading for translation would involve similar comprehension processes, parallel code-switching processes would increase WM (working memory) requirements when reading for translation" (p. 186).

Macizo and Bajo (2004) emphasise that "Thus, although translation seems to increase the time required for sentence processing, the meaning of the sentences is extracted as completely in translation as in normal reading" (p. 198). Macizo and Bajo (2004) come to a result that "Differences between normal reading and reading for translation are particularly large in the critical area where larger working memory demands are imposed, the end of the relative clause. But, why do instructions to translate slow down on-line sentence processing compared to normal reading? What additional processes are taking place when reading for translation? We think that when reading for translation, participants engaged in code-switching processes" (p. 199).

Van Els et al. (cited in Mahmoud, 2006, p. 31) also state that when translating a text, students come into contact with all the main ideas and specific details of a reading passage. Translation necessitates the close reading of the entire passage, which provides valuable information for the instructor. Translation can improve comprehension since it encourages students to read a passage carefully and precisely at the word, sentence, and text levels.

\section{METHODOLOGY}

\section{Research Design}

This pre-test post-test control group design, involving second year English Language Teaching Department students at the same proficiency levels, sought to determine if there is a significant difference in the number of correct items on the translation test after two different treatments, form and meaning focused translation instruction, were applied to the teaching of translation. Also, a reading comprehension test was administered to the students to determine if there is an impact of the reading levels of the student to their translation skills.

\section{Statement of the Problem}

Throughout the history of language teaching methodologies, researchers have continuously been in search of innovative ideas in order to make language teaching and learning process most effective and efficient for 
learners. Some of these ideas have been derived from second language acquisition (SLA) research and referred to language classroom applications and concerns. In the field of second language acquisition (SLA), grammar teaching has been a debate in language teaching instruction. The pedagogical approaches to grammar have been less effective for describing complex and multiple language phenomena and exceptions occurring when language was authentically used (Celce-Murcia, 1991). Therefore, the instructional methods of grammar have been theoretically and pedagogically changed in the language teaching settings. With the development of these instructional approaches to L2 grammar in the ELT context, grammar teaching has been continuously considered one of the crucial instructional components for SLA in the ELT context. One of the most frequently debated concerns so far has been whether to instruct the linguistic features of the language or to set the learners free to pick up these features of the language on their own (Pica, 2000).

There are many theories on how a language (L2) is learned, how to implement various approaches in the classroom, and how to measure learning. So forth, research over the years has resulted in an alteration of not only specific theories but also specialized terminology. More and more studies have been conducted on smaller and smaller aspects, and research in the field of teaching English to has subdivided into separate fields, two of which are second language acquisition (SLA) research and second language teaching and learning research. Because of the detail driven theories being put forward, researchers have a difficult time testing those theories in an actual classroom before they are accepted and implemented by language teachers. This study tests certain SLA theories in actual classrooms.

The question is which type of focus is most beneficial for foreign language learners. Is one or the other best or perhaps a combination? Over twenty years of research in Foreign Language Learning, this issue is a question of debate and divides both theory and research. Although research has been done in the classroom and the laboratory, in search of a resolution, the question remains unanswered (Leeman, Arteagoitia, Fridman \& Doughty, 1995, p. 217).

To summarize, due to these problems caused by the conflict between form and meaning focused instruction, it is essential to examine whether a form focused translation instructional approach might be more effective than the meaning focused translation instructional approach in Turkish ELT University level classroom contexts. These two treatments can be applied in the Translation course. 


\section{Research Questions}

The research was conducted in order to answer the following questions:

1. Will there be a difference in the translation and reading scores of the students in the experimental and control group?

2. Do students who are good in reading translate better than the poor or average readers?

3. Does translation improve the reading skill of the students?

\section{Participants}

The pre-post test control group design known as the unselective design is used in psychology and education frequently, as well. In this design, two groups are established unselectively from the preselected subject pool. One of the groups is identified as the experimental group and the other as the control group unselectively. Then, the dependant variable of the subjects in both groups before the treatment is measured. During the treatment the experimental treatment is applied to the experimental group. Finally the measurements of the subjects' dependent variables are repeated with the same tools or similar forms. The subject pool for the study consisted of 75 undergraduate students who have taken the Translation (from English to Turkish) at the Department of English Language Teaching, Gazi University: 40 for the experimental group, and 35 for the control group.

The translation course from English to Turkish is given in the first semester of the second year. The subjects took the translation course two hours per week. Four of the classes in the ELT program at this university were chosen for this current study. Two of them were assigned to the experimental group for the study, and the other two served as the control group.

\section{Materials and Procedures}

All subjects in the experimental and control groups received the same amount of treatment with two different types of instructional methods from two different teachers in their regular classes: the meaning focused instruction for the experimental group and the form focused instruction for the control group. The treatment was limited to instructional materials as Alan Duff's (1994) book titled "Translation" for the experimental group and Denis Chamberlin and Gillian White's (1983) book titled "Advanced English for Translation" for the control group. The books were designed for form and meaning focused translation instruction, therefore no additional material was used. The study extended over a period of 10 weeks. The experimental group students did not receive any grammatical explanations 
while the control group received explicit grammatical explanations during the treatment. The subjects took the Translation course for 10 weeks in the first term of the 2009-2010 academic year.

The Translation Test: The 'Translation Test' was developed through procedures that evaluated the content validity of identified statements, explored the criterion and construct validity, and assessed the internal reliability of the instrument. The test was created by three experts in the field of English Language Teaching. The sentences to be translated were chosen from Alan Duff's (1994) book titled "Translation". The Test Validity and Reliability: The content validity was of concern in the development of "Translation Test". A panel of experts, with expertise in English Language teaching, were used in the evaluation of validity of items. The panel used classification and sorting procedures in their efforts. The "Translation Test" was developed through procedures that evaluated the content validity of identified statements, explored the criterion and construct validity, and assessed the internal reliability of the instrument. Internal consistency focused on the degree to which the same characteristic was being measured. The Evaluation and Scoring of the Translation Test: The Translation test had 10 items (sentence(s)). Each sentence group was evaluated and scored by three experts in the field of English Language Teaching according to the answer sheet prepared by them. The researcher evaluated the main scores of the three experts' evaluation of the test and scored them in a scale from 1 to 4. The evaluation and scoring of the test was as below:

$0 \rightarrow$ Completely Incorrect (The form and meaning is completely incorrect).

$1 \rightarrow$ Incorrect (The form and meaning is slightly incorrect).

$2 \rightarrow$ Slightly Correct (The form is correct but the meaning is slightly incorrect).

$3 \rightarrow$ Correct (The form is slightly incorrect but meaning is correct).

$4 \rightarrow$ Perfect (The form and meaning is completely correct).

The pre-test and post-test of the Translation Test were evaluated and scored the same way. The statistical evaluation was done in accordance with the mean scores of the evaluators.

The Reading Comprehension Test: The reading comprehension questions were taken from the internet address of ÖSYM (Öğrenci Seçme ve Yerleştirme Merkezi - Student Selection and Placement Centre), www.osym.gov.tr. Details of the questions are given below: 
1-15 questions were taken from 2006 MAY KPDS EXAM (Questions 76-85, 96-100). 16-20 questions were taken from 2007 MAY KPDS EXAM (Questions 76-80).

The test has four paragraphs and five questions in each paragraph as a total of twenty questions. The items were evaluated according to the given right answers from the total of the questions. Then, the levels of the students were graded according to the total right answers given to the test. The grading of the students were as good readers, average readers and bad readers. The pre-test and post-test of the Reading Test were evaluated and scored the same way. The statistical evaluation was done in accordance with the scoring.

\section{Data Analysis}

The data gained from the data collection tools were analysed with the SPSS 15.0 programme.

\section{RESULTS AND DISCUSSION}

\section{The Comparison of the Groups' Reading Comprehension Achievement}

In this section, the findings and interpretation of the experimental and control groups students' pre-post test scores in reading comprehension test are stated.

\section{Pre-Test Scores of the Groups in the Reading Comprehension Test}

Table 1. The Independent T-Test Results for the Scores of the Experimental and Control Group Students' Reading Comprehension Pre-Test

\begin{tabular}{|c|c|c|c|c|c|c|}
\hline Group & $\mathbf{N}$ & $\bar{x}$ & $\mathbf{S}$ & sd & $\mathbf{t}$ & p \\
\hline Experimental & 40 & 12.500 & 2.562 & \multirow{2}{*}{73} & \multirow{2}{*}{1.023} & \multirow{2}{*}{.310} \\
\hline Control & 35 & 13.114 & 2.632 & & & \\
\hline
\end{tabular}

In order to check if there is a statistically significant difference in the reading comprehension of the experimental and control group students' pretests the Independent Sample t Test has been conducted. When the figures are examined in Table 1, it is seen that the difference between the arithmetic means of the groups' pre-test scores in the reading comprehension is not statistically significant $\left(\mathrm{t}_{(73)}=1.023, \mathrm{p}>.05\right)$. According to the data, the mean scores of the pre-test of the experimental group which was treated with meaning focused instruction was $(\bar{x}=12.500)$, and the mean scores of the pre-test of the control group which was treated with form focused instruction 
was $(\bar{x}=13.114)$. Therefore, the groups can be said to be equal in terms of reading comprehension skill in English before the treatment.

\section{The Comparison of the Groups' Translation Test}

In this section, the findings and interpretation of the experimental and control groups students' pre-post test scores in translation test are stated.

\section{Pre-Test Scores of the Groups in the Translation Test}

Table 2. The Independent T-Test Results for the Difference in the Scores of the Experimental and Control Group Students' Translation PreTest

\begin{tabular}{lllllll}
\hline Group & N & $\bar{x}$ & S & sd & t & p \\
\cline { 1 - 4 } Experimental & 40 & 20,650 & 4,560 & & & \\
\cline { 1 - 3 } Control & 35 & 21,942 & 4,886 & & & \\
\hline
\end{tabular}

In order to check if there is a statistically significant difference in the translation test scores of the experimental and control group students' pretests the Independent Sample t Test has been conducted. When the figures are examined in Table 2, it is found that the difference between the arithmetic means of the groups' pre-test scores in the translation test is not statistically significant $\left(\mathrm{t}_{(73)}=1.185, \mathrm{p}>.05\right)$. According to the data, the mean scores of the pre-test of the experimental group which was treated with meaning focused instruction was $(\bar{x}=20.650)$, the mean scores of the pretest of the control group which was treated with form focused instruction was ( $\bar{x}=21.942)$. Therefore, the groups can be said to be equal in terms of translation skills (from English to Turkish) before the treatment.

Correlating between the Academic Achievements of the Groups' Reading Comprehension and Translation Tests

Table 3. The Correlation Values for the Correlation between the Reading Comprehension and Translation Scores of the Experimental Group Students' PreTests

\begin{tabular}{|c|c|c|c|}
\hline & & Reading Test & Translation Test \\
\hline \multirow[t]{2}{*}{ Reading Test } & $\mathrm{r}$ & & 033 \\
\hline & $\mathrm{p}$ & & 840 \\
\hline \multirow[t]{2}{*}{ Translation Test } & $\mathrm{r}$ & ,033 & \\
\hline & $\mathrm{p}$ & 840 & \\
\hline
\end{tabular}


Table 3 illustrates that there is a low level positive correlation between the experimental group students' pre-tests scores of reading comprehension test and translation test $(\mathrm{r}=0.033, \mathrm{p}>.05)$.

Table 4. The Correlation Values for the Correlation between the Reading Comprehension and Translation Scores of the Control Group Students' Pre-Tests

\begin{tabular}{l|c|ll}
\hline \multicolumn{3}{l}{} & \multicolumn{3}{c}{ Reading Test } & Translation Test \\
\hline Reading Test & $\mathrm{r}$ & &, 217 \\
& $\mathrm{p}$ & &, 211 \\
\hline Translation Test & $\mathrm{r}$ &, 217 & \\
& $\mathrm{p}$ &, 211 & \\
\hline
\end{tabular}

As indicated in Table 4, a low level positive correlation has been identified between the control group students' pre-tests scores of reading comprehension test and translation test $(\mathrm{r}=0.217, \mathrm{p}>.05)$.

Table 5. The Correlation Values for the Correlation between the Reading Comprehension and Translation Scores of the Experimental Group Students' Post-

\begin{tabular}{|c|c|c|c|}
\hline \multicolumn{4}{|c|}{ Tests } \\
\hline & & Reading Test & \multirow{2}{*}{$\begin{array}{l}\text { Translation Test } \\
, 342(*)\end{array}$} \\
\hline Reading Test & $\mathrm{r}$ & & \\
\hline & $\mathrm{p}$ & &, 031 \\
\hline Translation Test & $\mathrm{r}$ &, $342(*)$ & \\
\hline & $\mathrm{p}$ & ,031 & \\
\hline
\end{tabular}

As revealed in Table 5, a intermediate level positive correlation has been noted between the experimental group students' post-tests scores of reading comprehension test and translation test $(\mathrm{r}=.342, \mathrm{p}<.05)$.

Table 6. The Correlation Values for the Correlation between the Reading Comprehension and Translation Scores of the Control Group Students' Post-Tests

\begin{tabular}{l|l|ll}
\hline \multicolumn{2}{l}{} & \multicolumn{3}{c}{ Reading Test } & Translation Test \\
\hline Reading Test & $\mathrm{r}$ & &,- 012 \\
& $\mathrm{p}$ & &, 947 \\
\hline Translation Test & $\mathrm{r}$ &,- 012 & \\
& $\mathrm{p}$ &, 947 & \\
\hline
\end{tabular}

As seen in Table 6, a low level negative correlation has been viewed between the control group students' post-tests scores of reading comprehension test and translation test $(\mathrm{r}=-0.012, \mathrm{p}>.05)$. 
The Evaluation of the Translation Test According to the Reading Comprehension Levels of the Groups

In this section, the findings and interpretation of the experimental and control groups students' translation scores in accordance to their reading comprehension levels are stated.

Table 7. The Kruskal Wallis Test Results of the Distribution of the Translation Scores of Poor Readers

\begin{tabular}{lllllll}
\hline Group & N & Mean Rank & sd & $\mathbf{X}^{\mathbf{2}}$ & $\mathbf{p}$ & Significant Difference \\
\hline Control Pre-Test & 1 & 5,00 & & & & \\
Control Post-Test & 7 & 8,36 & & & & \\
Experimental Pre-Test & 2 & 3,75 & 3 & 2,600 &, 457 & - \\
Experimental Post-Test & 3 & 6,67 & & & & \\
& & & & & & \\
\hline
\end{tabular}

As presented in Table 7, a significant difference has not been noticed in the scores of the translation test of poor readers $\left[x^{2}(3)=2.600, p>.05\right]$.

Table 8. The One-Way Variance Analysis (ANOVA) Test Results of the Distribution of the Translation Scores of Average Readers

\begin{tabular}{|c|c|c|c|c|c|c|}
\hline $\begin{array}{l}\text { Source of } \\
\text { Variance }\end{array}$ & $\begin{array}{l}\text { Sum of } \\
\text { Squares }\end{array}$ & $\begin{array}{l}\text { Square } \\
\text { Mean }\end{array}$ & sd & $\mathbf{F}$ & $\mathbf{P}$ & Significant Difference \\
\hline Between Groups & 522,783 & 174,261 & 3 & & & Experimental Post test- \\
\hline Within Groups & 3072,976 & 30,730 & 100 & 5,671 &, 001 & Control Pre test \\
\hline Total & 3595,760 & & 103 & & & $\begin{array}{l}\text { Experimental Post test - } \\
\text { Experimental Pre test }\end{array}$ \\
\hline
\end{tabular}

As Table 8 shows, significant difference has been observed in the scores of the translation test of average readers $\left(\mathrm{F}_{(3-100)}=5,671 ; \mathrm{p}<, 05\right)$. According to the Schefee Analysis done to determine the difference in the scores, the difference has been seen between the experimental group posttest and experimental group pre-test, and between the experimental group post-test and control group pre-test. This finding shows that meaning focused instruction treatment is more effective in the translation skills of average readers than form focused instruction treatment. 
Table 9. The One-Way Variance Analysis (ANOVA) Test Results of the Distribution of the Translation Scores of Good Readers

\begin{tabular}{lllllll}
\hline $\begin{array}{l}\text { Source of } \\
\text { Variance }\end{array}$ & $\begin{array}{l}\text { Sum of } \\
\text { Squares }\end{array}$ & $\begin{array}{l}\text { Square } \\
\text { Mean }\end{array}$ & sd & F & P & Significant Difference \\
\hline $\begin{array}{l}\text { Between } \\
\text { Groups }\end{array}$ & 288,419 & 96,140 & 3 & & & $\begin{array}{l}\text { Experimental Post test- } \\
\text { Control Pre test }\end{array}$ \\
$\begin{array}{l}\text { Within Groups } \\
\text { Total }\end{array}$ & 501,823 & 17,304 & 29 & $5,556,004$ & \\
& 790,242 & & 32 & & & $\begin{array}{l}\text { Experimental Post test - } \\
\text { Experimental Pre test }\end{array}$ \\
\hline
\end{tabular}

As seen in Table 9, significant difference has been seen in the scores of the translation test of good readers $\left(\mathrm{F}_{(3-29)}=5,556 ; \mathrm{p}<, 05\right)$. According to the Schefee Analysis done to determine the difference in the scores, the difference has been seen between the experimental group post-test and experimental group pre-test, and between the experimental group post-test and control group pre-test. This finding shows that meaning focused instruction treatment is more effective in the translation skills of good readers than form focused instruction treatment.

\section{CONCLUSION}

The findings of the correlation between the academic achievements of the groups' reading comprehension and translation tests show that there is a low level positive correlation between the experimental and control group students' pre-tests scores of reading comprehension test and translation test. As it is a low level positive correlation, it can be said that the correlation between the students' reading comprehension level has a low effect on the translation scores in the pre-tests of both groups. Furthermore, in the posttests, a medium level positive correlation has been found between the experimental group students' post-tests scores of reading comprehension test and translation test and there is also a low level negative correlation between the control group students' post-tests scores of reading comprehension test and translation test. This result shows that the students in the experimental group which took meaning focused translation instruction translated better than the students in the control group which took form focused translation instruction in relation with their reading comprehension scores. The finding also shows that there is a negative correlation in reading comprehension levels and translation test scores in the post-test of the control group. This shows that there was a decrease in the translation scores of the students in the control group in relation with their reading comprehension scores. Claramonte (1994, p. 190) states that if a learner fully applies the reading 
strategies in a text, he will be able to read that text correctly and, as a consequence, to translate it well.

One important outcome of the study is that the evaluation of the translation test results according to the reading comprehension levels of the groups shows that the difference in the scores of the translation test of poor readers' pre-post tests in the control and experimental group is not significant. But a significant difference has been noted in the scores of the translation test of average and good readers. The difference is between the experimental group post-test and experimental group pre-test, and between the experimental group post-test and control group pre-test of the average and good readers. The significant difference is in favour of the experimental group which took the meaning focused translation instruction treatment. According to the results, there wasn't a significant difference in the translation scores of the poor readers in the control and experimental group students. This means that there was no change in their translation test scores in the pre-test and post-test. The average and good readers in the experimental group have improved their translation skills more than the students in the control group. This finding shows that treatment with meaning focused translation instruction is more effective in increasing the translation skills of the average and good readers than the treatment with form focused translation instruction. It is a fact that for a good translation understanding the text fully is the most important factor. As good readers comprehend the text better than the lower ones they are to translate the text more correctly. Macizo and Bajo (2004, pp. 199-200) reported data indicating that when the participants were reading in the source language and they received instruction for later translation, some properties of the target language (e.g. cognate status of the words) had effects on their translation. Therefore, activation of the lexical entries in the target language seems to proceed in parallel to source language understanding.

The reason of the experimental group being more successful might be because of first, control group subjects only had the opportunity to form focused sub-skills: however, according to DeKeyser (1998) language learning occurs through practice integrating various sub-skills (i.e.. lower level and higher level). Second, the teacher in the form focused classroom provided explanations, modeling, and feedback but not in communicative contexts. The teacher gave form focused feedback during a controlled pair activity of translation. According to Long (1983), acquisition-rich environments refer to situations where there is exposure to comprehensible input outside of the classroom (e.g., English as a second language contexts). On the other hand, acquisition-poor environments refer to situations where 
learners have little or no access to comprehensible input (e.g., English as a foreign language context). Also, an activity which focuses on meaning, as defined by Ellis (2003): “...there must be a primary concern for message content (although this does not preclude attention to form), the participants must be able to choose the linguistic and non linguistic resources needed, and there must be a clearly defined outcome" (p. 141).

The study has the following limitations: a) one of the main limitations of this study is that it investigated only the students who take the Translation course. The sample of this study is limited to $2^{\text {nd }}$ year students in ELT Department, Gazi University, Ankara. This study is also limited to the course of translating from English into Turkish, b) the teacher, who delivered the form focused translation instruction treatment to the control group and the teacher who delivered the meaning focused translation instruction treatment to the experimental group are different teachers than the researcher. However, this issue is not considered in the discussion of the findings.

The following are some suggestions for further study: a) the study was conducted to the translation from L2 to L1. Most likely translating from L1 to L2 will show difference in the focus on the instruction types. The teachers and learners are aware that translating from L1 to L2 is more complicated and requires focusing on the form more than vice-versa, b) different types of material can be used for form and meaning focused translation instruction in the translation course. Usage of other types of authentic materials can show difference in the students' improvement.

\section{REFERENCES}

Basnett, S. (1998). Researching Translation Studies. In P. Bush \& K. Malmkjaer (Eds.), Rimbaud's Rainbow: Literary Translation in Higher Education (pp. 105-118). Amsterdam: John Benjamins.

Bozkurt, B.R., Coşkun, Y., Erol, B., Esin, G., \& Özer, S. (1982). Çeviri (3). Ankara: Metaksan.

Celce-Murcia, M. (1991). Grammar Pedagogy in Second and Foreign Language Teaching. TESOL Quarterly, 25(3), 459-480.

Chamberlin, D. \& White, G. (1983). Advanced English for Translation. Cambridge: Cambridge University Press.

Chastain, K. (1988). Developing Second Language Skills. Theory to Practice. 219, 222, 224, 25, 31, ( 3rd ed. ). U.S.A.: Harcourt Brace Jovanovich Publishers. 
Claramonte M. C. \& Vidal Á. (1994) Approaches to the Teaching of Translation. Revista Alicantina de Estudios Ingleses 7 (1994): 185-92.

Davies, F. (1995). Introducing Reading. Ronald Carter \& David Nunan (Editors) (p.66-70) England: Penguin English.

DeKeyser, R. M. (1998). Beyond Focus on Form: Cognitive Perspectives on Learning and Practicing Second Language Grammar. In C. Doughty \& J. Williams (Eds.), Focus on Form in Classroom Second Language Acquisition (pp. 42-63). Cambridge: Cambridge University Press.

Duff, A. (1994). Translation. Oxford: Oxford University Press. Ellis, R. (2003). Task-Based Language Learning and Teaching. Oxford: OUP.

Erer, N. G. (2006). Translation as an Integrated Approach in ELT. Microfilmed M.A. Dissertation. Graduate School of Education, Bilkent University.

Grabe, W. \& Stoller F. L. (2001). "Reading for Academic Purposes: Guidelines for ESL/EFL Teacher." In M. C. Murcia (Ed.), Teaching English as a Second or Foreign Language. (pp. 187-203), Heinle \& Heinle.

Grabe, W. \& Stoller F. L. (2002). Teaching and Researching Reading. Harlow: Pearson Education.

Grellet, F. (1981) Developing Reading Skills: Practical Guide to Reading Comprehension Exercises. Great Britain: Cambridge University Press.

Jakobson R. (1959). On Linguistic Aspects of Translation. In A. R. Brower (Ed.), On Translation (pp. 232-39). Cambridge, MA: Harvard University Press.

Johnston, P. H.(1983) Reading Comprehension Assessment: A Cognitive Basis. Newark, Delaware: International Association.

Jones, B. F. \& Palincsar, A. S. \& Ogle, D. S. \& Carr, E. G. (Ed.) (1987). Strategic Teaching and Learning: Cognitive Instruction in the Content Areas. Jones, B. F.Palincsar, A. S. \& Ogle, D. S. \& Carr, E. G.

Klein, M. L. (1988). Teaching Reading Comprehension and Vocabulary: A Guide for Teachers. UK: Prentice Hall Publication.

Leeman,J., Arteagoitia I., Fridman, B. \& Doughty, C. (1995). Integrating Attention to Form with Meaning: Focus on Form in Content based Spanish Instruction. In Richard W. Schmidt (Eds.) Attention and 
Awareness in Foreign Language Learning, 217-258. Honolulu, HI: University of Hawai'i, Second Language Teaching and Curriculum Centre.

Lin, J-W. (2002). Choice Functions and the Interpretation of Indefinite Polarity Wh-Phrases. Paper presented at GLOW in Asia 2002.).

Long, M. (1983). Does Second Language Instruction Make a Difference? A Review of Research. TESOL Quarterly, 17, 359-382.

Macizo, P. \&Bajo M. T. (2004). When Translation Makes the Difference: Sentence Processing in Reading and Translation. Psicológica (2004), 25, 181-205.

Mahmoud A. (2006) Translation and Foreign Language Reading Comprehension: A Neglected Didactic Procedure. English Teaching Forum, 44 (4).

Newmark, P. (1988). A Textbook of Translation. New York: Prentice Hall.

Nida, E. A. (1975a). Componential Analysis of Meaning; an Introduction to Semantic Structures. Paris: The Hage.

Nida, E. A. (1975b). Language Structure and Translation: Essays. Stanford, California: Stanford University Press.

Pica, T. (2000). Tradition and Transition in English Language Methodology. System, 28, 1-18.

Retorta, M. S. (2006) Multiple-Choice And Cloze Tests: What Do They Really Measure?, Retrieved from http://www.cefetpr.br/deptos/dacex/mirian4.htm, 2006.

Riley, P. M. (1977) Scientific Skills for Second and Post Secondary ESL Learners, TEFL/TESL Newsletter, 3, 1977, pp.1-6.

Shiyab S. \& Abdullateef M. (2001). Translation and Foreign Language Teaching. J. King Saud Univ., Vol. 13,Language \& Translation, pp. 19 (A H. 1421/2001).

Singer, H. (1994). The Substrata-Factor Theory of Reading. In R.B. Ruddell, M.R. Ruddell \& H. Singer, Theoretical Models and Processes of Reading. (pp. 895- 927). Newark, DE: International Reading Association.

Webb, J. T. (1994). Tadutore, traditore? (Translation in ELT). Unpublished manuscript. 
